\title{
Treatment of landfill leachate: Removal of ammonia by struvite formation
}

\author{
CC Camargo', JR Guimarães' ${ }^{1}$ and AL Tonetti ${ }^{*}$ \\ 'School of Civil Engineering, Architecture and Urbanism, FEC/UNICAMP, Avenida Albert Einstein, 951, Cidade Universitária 'Zeferino Vaz', \\ PO Box 6021, 13083-852, Campinas, SP, Brazil
}

\begin{abstract}
This paper presents a study of ammoniacal nitrogen removal by chemical precipitation resulting in the formation of ammonium and magnesium phosphat $\left(\mathrm{MgNH}_{4} \mathrm{PO}_{4} \cdot 6 \mathrm{H}_{2} \mathrm{O}\right)$, known as struvite, from the leachate in the Delta $\mathrm{A}$ landfill, located in the city of Campinas, São Paulo, Brazil. After the addition of a magnesium source $\left(\mathrm{MgCl}_{2} \cdot 6 \mathrm{H}_{2} \mathrm{O}\right)$, and phosphorus $\left(\mathrm{Na}_{2} \mathrm{HPO}_{4} \cdot 12 \mathrm{H}_{2} \mathrm{O}\right)$, ammoniacal nitrogen was precipitated as highly insoluble salt. The removal of ammoniacal nitrogen from the leachate exceeded $85 \%$ when the reaction was performed at an initial $\mathrm{pH}$ of 10.0 . The highest efficiencies were achieved when the molar ratio between the ions involved in the reaction, i.e., $\mathrm{Mg}^{2+}: \mathrm{PO}_{4}^{3-}: \mathrm{NH}_{4}^{+}$, was 1.2:1.0:1.0, respectively.

Keywords: landfill, leachate, ammonia, nitrogen removal
\end{abstract}

\section{INTRODUCTION}

Brazil has a daily production of about 260000 tons of municipal solid waste (IBGE, 2008). Of this total, approximately $65 \%$ is disposed in landfills, considered to be the most appropriate form of disposal within the Brazilian context (Povinelli and Além Sobrinho, 2009). However, from an environmental point of view, there are problems that should be addressed inside the landfill, such as the emission of greenhouse gases (GHG), and the generation of leachate from rainwater and residue decomposition.

The leachate has unique characteristics, such as a high concentration of ammoniacal nitrogen $\left(\mathrm{NH}_{3}\right.$ and $\left.\mathrm{NH}_{4}^{+}\right)$, high chemical oxygen demand, low potential for biological degradation, and the presence of metals and other organic and inorganic substances that confer a high toxicity to this type of waste, and hinder its treatment. Studies by Clément and Merlin (1995) indicate that ammoniacal nitrogen in its nonionized form $\left(\mathrm{NH}_{3}\right)$ is the major contributor to the toxicity of the leachate. Li and Zhao (1999) argue that its concentration in leachate must be reduced to at least $100 \mathrm{mg} \cdot \ell^{-1}$ prior to its entry into biological reactors for activated sludge.

Chemical precipitation in the form of the double salt of magnesium and ammonium phosphate, also known as struvite, is one of several options for removing ammoniacal nitrogen from this matrix. Struvite is an inorganic mineral in the form of a white crystal, with a chemical formula of $\mathrm{MgNH}_{4} \mathrm{PO}_{4} \cdot 6 \mathrm{H}_{2} \mathrm{O}$. Struvite is highly soluble in acid, and insoluble in a basic medium; the $\mathrm{pH}$ of minimum solubility is around 9.0 (Munch and Barr, 2001). Moreover, as a slow release source of phosphorus, magnesium, and nitrogen, struvite is a potentially valuable fertiliser (Iaconi et al., 2010).

Based on these facts, the aim of this work was to reduce the ammoniacal nitrogen concentration of a landfill leachate by

To whom all correspondence should be addressed 용 +55 19 3521-2369; e-mail: adriano@fec.unicamp.br Received 27 September 2013; accepted in revised form 30 June 2014. chemical precipitation in the form of struvite, by evaluating the efficiency of the treatment, the $\mathrm{pH}$ of the medium, and the ratio between the reagents.

\section{MATERIALS AND METHODS}

The leachate used for the experiments originated in the main landfill of the city of Campinas, in the state of São Paulo, Brazil. This landfill occupies an area of $400000 \mathrm{~m}^{2}$, and responded to the completion of this work by receiving $100 \%$ of household waste generated in the city, averaging $1000 \mathrm{t} \cdot \mathrm{day} \mathrm{y}^{-1}$. Operations began in 1992, and in 2011 the production of leachate was approximately $10.4 \mathrm{~m}^{3} \cdot \mathrm{h}^{-1}$.

The raw leachate samples were collected and brought to the Laboratory of the School of Civil Engineering, Architecture, and Urbanism (FEC), at the University of Campinas (Unicamp).

The reagents used in the precipitation test were chosen based on the work of Li et al. (1999). According to these authors, the combination of $\mathrm{MgCl}_{2} \cdot 6 \mathrm{H}_{2} \mathrm{O}$ with $\mathrm{Na}_{2} \mathrm{HPO}_{4} \cdot 12 \mathrm{H}_{2} \mathrm{O}$ is the most efficient in removing ammoniacal nitrogen.

Before conducting the tests, a sample of the raw leachate was analysed to determine the ammoniacal nitrogen $\left(\mathrm{NH}_{4}^{+}+\right.$ $\mathrm{NH}_{3}$ ) concentrations. From the obtained values, the amounts of reagents $\left(\mathrm{MgCl}_{2} \cdot 6 \mathrm{H}_{2} \mathrm{O}\right.$ and $\left.\mathrm{Na}_{2} \mathrm{HPO}_{4} \cdot 12 \mathrm{H}_{2} \mathrm{O}\right)$ to be used in each test were calculated, according to the desired molar ratio of $\mathrm{Mg}^{2+}: \mathrm{NH}_{4}^{+}: \mathrm{PO}_{4}^{3-}$. Table 1 shows the ammoniacal nitrogen concentrations found, in addition to the molar ratios and $\mathrm{pH}$ values evaluated in the various experiments.

The experimental part was carried out according to the flowchart shown in Fig. 1. The leachate was placed in 6 jars and $\mathrm{pH}$ was adjusted with solutions of $\mathrm{NaOH} 15 \mathrm{~mol} \cdot \ell^{-1}$ and $\mathrm{H}_{2} \mathrm{SO}_{4}$ $6 \mathrm{~mol} \cdot \ell^{-1}$, followed by the addition of the reagents $\mathrm{MgCl}_{2} \cdot 6 \mathrm{H}_{2} \mathrm{O}$ and $\mathrm{Na}_{2} \mathrm{HPO}_{4} \cdot 12 \mathrm{H}_{2} \mathrm{O}$.

The tests were conducted in a jar test apparatus, consisting of 6 vessels with the following dimensions: $20.0 \times 11.5 \times 11.5$ $\mathrm{cm}$. Each vessel had a capacity of $2 \ell$, which resulted in a water depth of $15 \mathrm{~cm}$ and surface area of about $132 \mathrm{~cm}^{2}$. 


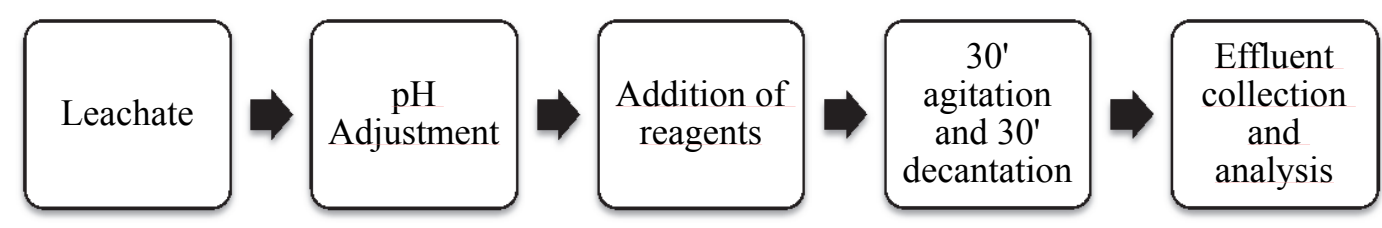

Figure 1

Test flow chart with $\mathrm{pH}$ adjustment prior to the addition of reagents

\begin{tabular}{|l|c|c|c|c|}
\hline \multicolumn{5}{|c|}{ TABLE 1} \\
Test & $\begin{array}{c}\mathrm{NH}_{3}-\text { leachate } \\
\left(\mathbf{m g} \cdot \ell^{-1}\right)\end{array}$ & $\mathbf{M g}^{2+}(\mathbf{m o l})$ & $\mathrm{PO}_{4}{ }^{3-}(\mathbf{m o l})$ & $\mathrm{pH}$ \\
\hline 1 & 1468.3 & 1.0 & 1.0 & $\begin{array}{c}9.5 / 10.0 / 10.5 \\
11.0 / 11.5 / 12\end{array}$ \\
\hline 2 & 1737.6 & $\begin{array}{l}0.0 / 0.2 / 0.4 \\
0.6 / 0.8 / 0.9\end{array}$ & $0.0 / 0.2 / 0.4$ & $0.6 / 0.8 / 0.9$ \\
\hline 3 & 1843.2 & $\begin{array}{r}1.0 / 1.2 / 1.4 \\
1.6 / 1.8 / 2.0\end{array}$ & 1.0 & 10.0 \\
\hline
\end{tabular}

In each test the samples were subjected to $30 \mathrm{~min}$ of reaction, with stirring at $100 \mathrm{r} \cdot \mathrm{min}^{-1}$, the velocity gradient equivalent to $64 \mathrm{~s}^{-1}$, and $30 \mathrm{~min}$ of decantation, followed by the collection of $500 \mathrm{ml}$ samples from the hole at the centre of the jar. The samples were subjected to the following analyses: $\mathrm{pH}$, conductivity (cond), ammoniacal nitrogen $\left(\mathrm{NH}_{4}{ }^{+}+\mathrm{NH}_{3}\right)$, total Kjeldahl nitrogen (TKN), phosphorus (P), chemical oxygen demand (COD), and magnesium (Mg). All techniques were performed according to the guidelines established in the Standard Methods for the Examination of Water and Wastewater (APHA et al., 2012).

\section{Tests without addition of reagents}

To assess the possible volatilisation loss of the ammonia gas, as well as the precipitation of phosphorus in a different form than struvite, a test was conducted without the addition of the two principal reagents. In this case, only the $\mathrm{pH}$ was adjusted, and the next steps of the procedure were maintained, with the 30 min reaction and decantation time.

\section{RESULTS AND DISCUSSION}

Table 2 shows that the leachate had low BOD, low BOD/COD ratio, a $\mathrm{pH}$ around 8.0 , and high concentrations of ammoniacal nitrogen.

\begin{tabular}{|l|l|}
\hline \multicolumn{2}{|c|}{ TABLE 2 } \\
$\begin{array}{l}\text { Mean values of the parameters from the raw } \\
\text { leachate originating from the Delta A landfill }\end{array}$ \\
\hline Parameters & Value \\
\hline $\mathrm{pH}$ & $8.14 \pm 0.15$ \\
\hline BOD $\left(\mathrm{mgO}_{2} \cdot \ell^{-1}\right)$ & $173 \pm 38$ \\
\hline $\mathrm{COD}\left(\mathrm{mgO}_{2} \cdot \ell^{-1}\right)$ & $2386 \pm 485$ \\
\hline BOD/COD & 0.07 \\
\hline Ammoniacal nitrogen $\left(\mathrm{mg} \cdot \ell^{-1}\right)$ & $1716.1 \pm 293.8$ \\
\hline Phosphorus $\left(\mathrm{mg} \cdot \ell^{-1}\right)$ & $22.9 \pm 3.8$ \\
\hline Conductivity $\left(\mathrm{mS} \cdot \mathrm{cm}^{-1}\right)$ & $24.75 \pm 3.51$ \\
\hline Magnesium $\left(\mathrm{mg} \cdot \ell^{-1}\right)$ & $152 \pm 28$ \\
\hline Total Solids $\left(\mathrm{mg} \cdot \ell^{-1}\right)$ & 10416 \\
\hline Fixed Solids $\left(\mathrm{mg} \cdot \ell^{-1}\right)$ & 7770 \\
\hline Volatile Solids $\left(\mathrm{mg} \cdot \ell^{-1}\right)$ & 2646 \\
\hline
\end{tabular}

Table 3 shows the results corresponding to Test 1 , wherein the molar ratio $\mathrm{Mg}^{2+}: \mathrm{NH}_{4}{ }^{+}: \mathrm{PO}_{4}{ }^{3-}$ was 1.0:1.0:1.0, respectively, and the $\mathrm{pH}$ varied between 9.5 and 12.0 (Table 1). Under these conditions the ammoniacal nitrogen removal efficiency was at least $77.8 \%$, reaching $89.1 \%$ when the $\mathrm{pH}$ was adjusted to 10.0 ; the final concentration was $159.4 \mathrm{mg} \cdot \ell^{-1}$.

There was a decrease in $\mathrm{pH}$ at the end of the reaction, which, according to Li et al. (1999) can be explained by the analysis of Eq. (1). The reaction between magnesium cations and phosphate anions releases acid $\mathrm{H}_{3} \mathrm{O}^{+}$ions into the solution, causing a decrease in $\mathrm{pH}$ values. There was an increase in the conductivity of the solution, from 22.64 to $39.40 \mathrm{mS} \cdot \mathrm{cm}^{-1}$, as a result of the increase in $\mathrm{H}_{3} \mathrm{O}^{+}$ions, which have a high ionic conductivity. The solution also displayed increased concentrations of $\mathrm{Na}^{+}$and $\mathrm{Cl}^{-}$, as a result of the reagents used.

$$
\mathrm{Mg}_{(\text {aq })}^{2+}+\mathrm{HPO}_{4(\mathrm{aq})}^{2}+\mathrm{NH}_{4(\mathrm{aq})}^{+} \stackrel{\mathrm{H}_{2} \mathrm{O}}{\Rightarrow} \mathrm{MgNH}_{4} \mathrm{PO}_{4(\mathrm{~s})} \downarrow+\mathrm{H}_{3} \mathrm{O}_{(\mathrm{aq})}^{+}
$$

The magnesium and phosphorus concentrations decreased,

\begin{tabular}{|c|c|c|c|c|c|c|c|}
\hline & & Resu & $\begin{array}{l}3 \\
\mathrm{n} \text { Test } 1\end{array}$ & & & & \\
\hline Parameters & Leachate & & & & & & \\
\hline & & 9.50 & 10.00 & 10.50 & 11.00 & 11.50 & 12.00 \\
\hline Initial pH & 8.08 & 9.48 & 10.00 & 10.47 & 11.01 & 11.49 & 12.00 \\
\hline Final pH & 8.08 & 7.18 & 8.83 & 9.66 & 10.10 & 10.37 & 10.58 \\
\hline Ammoniacal nitrogen $\left(\mathrm{mg} \cdot \ell^{-1}\right)$ & 1468.3 & 224.6 & 159.4 & 181.1 & 224.6 & 289.8 & 326.0 \\
\hline Ammoniacal nitrogen Removal (\%) & - & 84.7 & 89.1 & 87.7 & 84.7 & 80.3 & 77.8 \\
\hline $\mathrm{P}\left(\mathrm{mg} \cdot \ell^{-1}\right)$ & 20.9 & 467.6 & 177.7 & 100.3 & 92.8 & 35.3 & 30.3 \\
\hline N-NTK (mg. $\left.\ell^{-1}\right)$ & 1485.2 & 297.1 & 202.9 & 224.6 & 275.3 & 318.8 & 347.8 \\
\hline Conductivity $\left(\mathrm{mS} \cdot \mathrm{cm}^{-1}\right)$ & 21.48 & 36.24 & 38.48 & 43.95 & 46.35 & 48.21 & 47.10 \\
\hline $\operatorname{Mg}\left(m g \cdot \ell^{-1}\right)$ & 130 & 110 & 20 & 30 & 18 & 32 & 56 \\
\hline
\end{tabular}


along with the final ammonia concentration; a result consistent with struvite formation. However, the phosphorus values were still very high, always exceeding $30 \mathrm{mg} \cdot \ell^{-1}$.

According to the results from Test 1 , the $\mathrm{pH}$ of the solutions, in the subsequent stages, was adjusted to 10.0. In Test 2 (Table 4) the molar ratio of magnesium and phosphorus varied from 0.0 to 0.9 (Table 1), aiming at a reduction in the final concentration of phosphorus. A value of $1 \mathrm{mg} \cdot \ell^{-1}$ for phosphorus is stipulated by the state of Rio Grande do Sul (Brazil), as the upper limit for release into water bodies (CONSEMA 128, 2006).

Table 4 shows that with an increasing molar ratio the final concentration of phosphorus increased in the treated leachate as well. Even for the smallest ratios, phosphorus still exceeded $1 \mathrm{mg} \cdot \ell^{-1}$. The ammoniacal nitrogen removal was more effective for a molar ratio of $\mathrm{Mg}^{2+}: \mathrm{NH}_{4}{ }^{+}: \mathrm{PO}_{4}{ }^{3}$ of 0.8:1.0:0.8 (75.7\%). Taking into account the data presented in Table 3, it follows that for a molar ratio of 1.0:1.0:1.0 removal reached $89.1 \%$. These results demonstrate that a decrease in the molar ratio of the reactants is not advised when the primary purpose is ammoniacal nitrogen removal.

In Test 3 (Table 5) higher levels of magnesium, in relation to other compounds, were added in an attempt to decrease the residual concentration of phosphorus without compromising the ammonia removal. The procedure was effective, and a molar ratio of 2.0:1.0:1.0 resulted in a final concentration of phosphorus equivalent to $3.6 \mathrm{mg} \cdot \ell^{-1}$. It is noteworthy that, besides the phosphorus present in the raw leachate, more is added as part of one of the reagents.

However, the increase in the molar ratios of magnesium led to a decrease in ammonia removal. This phenomenon can be explained by a greater interaction of magnesium with phosphorus; thus, forming compounds other than struvite. Michalowsky and Pietrzyk (2006) report that there are 4 species of magnesium phosphate, which can crystallize from solutions containing ammonia, magnesium, and phosphate: ammonium phosphate and hexahydrate magnesium (struvite, $\mathrm{MgNH}_{4} \mathrm{PO}_{4} \cdot 6 \mathrm{H}_{2} \mathrm{O}$ ), magnesium hydrogen phosphate (newberyite, $\mathrm{MgHPO}_{4} \cdot 3 \mathrm{H}_{2} \mathrm{O}$ ), and trimagnesium phosphate in two hydration states: $\mathrm{Mg}_{3}\left(\mathrm{PO}_{4}\right)_{2} \cdot 22 \mathrm{H}_{2} \mathrm{O}$ and $\mathrm{Mg}_{3}\left(\mathrm{PO}_{4}\right)_{2} \cdot 8 \mathrm{H}_{2} \mathrm{O}$ (boberyite). Thus, the best result for the removal of ammoniacal nitrogen was obtained using a molar ratio of 1.2:1.0:1.0.

\section{Test without addition of reagents}

In Test 4 (Table 6), only the $\mathrm{pH}$ was adjusted and no reagents were added. This procedure was performed to evaluate the potential loss of ammonia by evaporation, and the phosphorus precipitation caused by the $\mathrm{pH}$ of the medium.

It was observed that by increasing the $\mathrm{pH}$ there was a higher rate of ammonia loss by volatilisation. With $\mathrm{pH}$ 10.0, the ammoniacal nitrogen decreased by $4.7 \%$. It is important to note that in the Standard Conditions of Pressure and Temperature (CNPT), the equilibrium constant of ammonia is $1.8 \times 10^{-5}$; therefore, the $p K_{b}$ is 4.74 ; i.e., at $\mathrm{pH} 9.26$ half of the ammoniacal nitrogen from the medium is in the ammonia form. This value increases exponentially as the solution becomes more basic, forming ammonia gas that can escape into the atmosphere. There is also a reduction in phosphorus concentration, probably caused by precipitation. According to Diamadopoulos and Benedek (1984), this precipitation can be attributed to the interaction between the calcium and phosphates, forming a stable compound (hydroxyapatite $\mathrm{Ca}_{10}$ $\left.\left(\mathrm{PO}_{4}\right)_{6}(\mathrm{OH})_{2}\right)$.

\begin{tabular}{|c|c|c|c|c|c|c|}
\hline \multicolumn{7}{|c|}{$\begin{array}{c}\text { TABLE } 4 \\
\text { Results from Test } 2\end{array}$} \\
\hline \multirow[t]{2}{*}{ Parameters } & \multirow[t]{2}{*}{ Leachate } & \multicolumn{5}{|c|}{ Molar ratio of $\mathrm{Mg}^{2+}: \mathrm{NH}_{4}^{+}: \mathrm{PO}^{3-}$} \\
\hline & & $0.0: 1.0: 0.0$ & $0.2: 1.0: 0.2$ & $0.4: 1.0: 0.4$ & $0.6: 1.0: 0.6$ & $0.8: 1.0: 0.8$ \\
\hline initial $\mathrm{pH}$ & 8.41 & 10.03 & 10.03 & 10.05 & 10.02 & 10.06 \\
\hline Final pH & 8.41 & 9.75 & 9.64 & 9.52 & 9.29 & 9.17 \\
\hline Ammoniacal nitrogen $\left(\mathrm{mg} \cdot \ell^{-1}\right)$ & 1737.6 & 1667.3 & 1132.6 & 1013.0 & 731.6 & 422.1 \\
\hline Ammoniacal nitrogen removal (\%) & - & 4.0 & 34.8 & 41.7 & 57.9 & 75.7 \\
\hline $\mathrm{P}\left(\mathrm{mg} \cdot \ell^{-1}\right)$ & 23.7 & 17.6 & 5.2 & 9.3 & 16.3 & 56.0 \\
\hline N-NTK $\left(\mathrm{mg} \cdot \ell^{-1}\right)$ & 1801.0 & 1716.5 & 1425.8 & 1078.7 & 816.1 & 422.1 \\
\hline Conductivity $\left(\mathrm{mS} \cdot \mathrm{cm}^{-1}\right)$ & 24.22 & 26.38 & 30.32 & 34.18 & 37.48 & 43.35 \\
\hline $\mathrm{Mg}\left(\mathrm{mg} \cdot \ell^{-1}\right)$ & 150 & 150 & 88 & 52 & 36 & 18 \\
\hline
\end{tabular}

\begin{tabular}{|c|c|c|c|c|c|c|c|}
\hline \multicolumn{8}{|c|}{$\begin{array}{c}\text { TABLE } 5 \\
\text { Results from Test } 3\end{array}$} \\
\hline \multirow[t]{2}{*}{ Parameters } & \multirow[t]{2}{*}{ Leachate } & \multicolumn{6}{|c|}{ Molar ratio of $\mathrm{Mg}^{2+}: \mathrm{NH}_{4}^{+}: \mathrm{PO}_{4}^{3-}$} \\
\hline & & 1.0:1.0:1.0 & 1.2:1.0:1.0 & 1.4:1.0:1.0 & 1.6:1.0:1.0 & 1.8:1.0:1.0 & $2.0: 1.0: 1.0$ \\
\hline Initial pH & 7.89 & 10.03 & 10.03 & 10.03 & 10.03 & 10.03 & 10.03 \\
\hline Final pH & 7.89 & 9.74 & 9.54 & 9.39 & 9.24 & 9.15 & 9.04 \\
\hline Ammoniacal nitrogen $\left(\mathrm{mg} \cdot \ell^{-1}\right)$ & 1843.2 & 316.6 & 218.1 & 267.3 & 274.4 & 394.0 & 400.1 \\
\hline Ammoniacal nitrogen removal (\%) & & 82.8 & 88.2 & 85.5 & 85.1 & 78.6 & 78.3 \\
\hline $\mathrm{COD}\left(\mathrm{mg} \cdot \ell^{-1}\right)$ & 2370 & 2147 & 2122 & 2109 & 2134 & 2085 & 2134 \\
\hline $\mathrm{P}\left(\mathrm{mg} \cdot \ell^{-1}\right)$ & 21.0 & 357.7 & 8.7 & 6.4 & 4.9 & 3.8 & 3.6 \\
\hline N-NTK $\left(\mathrm{mg} \cdot \ell^{-1}\right)$ & 1894.8 & 394.0 & 262.6 & 328.3 & 337.7 & 469.0 & 469.0 \\
\hline Conductivity $\left(\mathrm{mS} \cdot \mathrm{cm}^{-1}\right)$ & 26.26 & 52.83 & 54.21 & 56.46 & 62.68 & 65.20 & 67.72 \\
\hline $\operatorname{Mg}\left(\mathrm{mg} \cdot \ell^{-1}\right)$ & 160 & 20 & 340 & 720 & 180 & 2000 & 2400 \\
\hline
\end{tabular}




\begin{tabular}{|c|c|c|c|c|c|c|c|}
\hline \multicolumn{8}{|c|}{$\begin{array}{c}\text { TABLE } 6 \\
\text { Results from Test } 4 \\
\end{array}$} \\
\hline \multirow[t]{2}{*}{ Parameters } & \multirow[t]{2}{*}{ Leachate } & \multicolumn{6}{|c|}{ Desired pH } \\
\hline & & 9.00 & 9.50 & 10.00 & 10.50 & 11.00 & 11.50 \\
\hline Initial pH & 8.14 & 9.00 & 9.50 & 10.01 & 10.50 & 11.00 & 11.50 \\
\hline Ammoniacal nitrogen $\left(\mathrm{mg} \cdot \ell^{-1}\right)$ & 1755.7 & 1746.1 & 1691.7 & 1673.6 & 1673.6 & 1702.6 & 1622.9 \\
\hline Ammoniacal nitrogen removal (\%) & & 0.5 & 3.6 & 4.7 & 4.7 & 3.0 & 7.6 \\
\hline $\mathrm{P}\left(\mathrm{mg} \cdot \mathrm{l}^{-1}\right)$ & 24.2 & 24.3 & 23.6 & 23.8 & 24.0 & 21.4 & 9.1 \\
\hline $\mathrm{NTK}\left(\mathrm{mg} \cdot \ell^{-1}\right)$ & 1782.3 & 1787.1 & 1748.5 & 1738.8 & 1738.8 & 1709.8 & 1700.2 \\
\hline Conductivity $\left(\mathrm{mS} \cdot \mathrm{cm}^{-1}\right)$ & 23.50 & 23.66 & 23.88 & 25.30 & 27.28 & 29.28 & 31.12 \\
\hline
\end{tabular}

\section{CONCLUSIONS}

Chemical precipitation by struvite formation was effective in removing ammoniacal nitrogen from the leachate; reaching removal levels greater than $85 \%$ when the initial $\mathrm{pH}$ was equal to 10.0. The most suitable molar ratio for $\mathrm{Mg}^{2+}: \mathrm{PO}_{4}^{3-}: \mathrm{NH}_{4}^{+}$was 1.2:1.0:1.0 for the removal of ammoniacal nitrogen.

\section{REFERENCES}

APHA, AWWA, WEF (2012) Standard Methods for Examination of Water and Wastewater $\left(20^{\text {th }}\right.$ edn.) United Book Press, Baltimore.

CLÉMENT B, MERLIN G (1995) The contribution of ammonia and alkalinity to landfill leachate toxicity to duckweed. Science Total Environ. 170 71-79.

CONAMA (2011) Conselho Nacional do Meio Ambiente - Resoluções CONAMA $n^{\circ}$ 357, 17 de março de 2005. Ministério do Meio Ambiente, Distrito Federal.

CONSEMA (CONSELHO ESTADUAL DO MEIO AMBIENTE) (2006) Resolução $n^{\circ} 128$. Dispõe sobre a fixação de padrões de emissão de efluentes líquidos para fontes de emissão que lancem seus efluentes em águas superficiais no Estado do Rio Grande do Sul. Secretaria do Meio Ambiente, Rio Grande do Sul.

DIAMADOPOULOS E and BENEDEK A (1984) The precipitation of phosphorus from wastewater through $\mathrm{pH}$ variation in the presence and absence of coagulants. Water Res. 18 (9) 1175-1179.

IACONI C, PAGANO M, RAMADORI R and LOPEZ A (2010) Nitrogen recovery from a stabilized municipal landfill leachate. Bioresour. Technol. 101 1732-1736.

IBGE (2011) Pesquisa Nacional de Saneamento Básico. Instituto Brasileiro de Geografia e Estatística, Distrito Federal.

LI XZ, ZHAO QL and HAO XD (1999) Ammonium removal from landfill leachate by chemical precipitation. Waste Manag. 19 409-415.

MICHALOWSKY T and PIETRZYK A (2006) A thermodynamic study of struvite + water system. Talanta 68 594-601.

MUNCH E and BARR K (2001) Controlled struvite crystallization for removing phosphorus from anaerobic digester sidestreams. Water Res. 35 (1) 151-159.

POVINELLI J and ALÉM SOBRINHO P (2009) Introdução. In: Gomes LP (ed.) PROSAB. Resíduos Sólidos - Estudos de Caracterização e Tratabilidade de Lixiviados de Aterros Sanitários para as Condições Brasileiras. ABES, Rio de Janeiro. 